\title{
Shikimic and Salicylic Acids Induced Resistance in Faba Bean Plants against Chocolate Spot Disease
}

\author{
Heshmat Aldesuquy*, Zakaria Baka and Nahla Alazab
}

Botany Department, Faculty of Science, Mansoura University, Egypt

\begin{abstract}
Surveys for faba bean chocolate spot disease covering 6 districts in Delta of Egypt were conducted. Out of these surveys, six isolates of the pathogen were obtained and purified using single spore technique. These isolates were identified as Botrytis fabae. All isolates were subjected to pathogenicity tests to determine the most aggressive one. All isolates appear to have the potency to cause chocolate spot disease, but the isolate from Sherbin was considered to be the most aggressive one and was selected for further studies. In vitro, the effect of provided phenolic compounds on inhibition of mycelia growth and the growth rate of $B$. fabae was investigated and arranged as follows: salicylic acid > Shikimic acid > shikimic acid+salicylic acid, as compared to control values. Furthermore, significant reduction in the disease incidence (\%) and severity (\%) were recorded in faba bean plants treated with salicylic acid followed by shikimic acid then their interaction.

Botrytis fabae infection caused noticeable increase in the activity of defense enzymes (i.e., peroxidase, polyphenol oxidase and phenyl alanine ammonia lyase) in infected faba bean plants. In the majority of cases, the applied phenolic compounds induced additional increase in such enzymes than that sprayed with fungicide. This increment was concomitant with the increase in the endogenous total phenols, shikimic acid and salicylic acid content. In addition, the most effective treatment in enhancement faba bean resistance against $B$ fabae infection was salicylic acid at $0.7 \mathrm{mM}$.
\end{abstract}

Keywords: Faba bean; Chocolate spot disease; Oxidative enzymes; Shikimic acid; Salicylic acid

\section{Introduction}

The faba bean (Vicia faba L.) is considered as one of the most profitable field crops in Egypt. The plant is grown mainly for its green pods and dried seeds, which are rich in a protein (18.5 to $37.8 \%)$ that can substitute for animal protein in humans, as well as other compounds [1]. However, the faba bean is susceptible to attack by many diseases, such as chocolate spot disease caused mainly by Botrytis fabae and diseases are responsible for considerable losses in seed yield [2]. Peroxidases oxidize phenols to quinines, which are toxic to pathogens. Peroxidases participate in a broad range of physiological processes, such as the formation of lignin and suberin, the cross-linking of cell wall components, and phytoalexin synthesis. Peroxidase also functions in the metabolism of Reactive Oxygen Species (ROS) and Reactive Nitrogen Species (RNS), thus activating the Hypersensitive Response (HR), a form of programmed cell death at the infection site that is associated with limiting pathogen development [3]. Polyphenol oxidases participate in the oxidation of aromatic substrates and dihydroxyphenolic compounds in the presence of oxygen in host tissues, producing quinones that are toxic to pathogens [4].

The effect of $B$. fabae infection in the two faba bean varieties caused biochemical changes in the content of phenolic, oxidative enzymes, phytoalexins and free amino acids. HPLC analysis showed that the resistant cultivar Giza 461 demonstrated significantly higher amounts of oxidative enzymes, free, conjugated and total phenols and phytoalexins compared with the highly susceptible cultivar Giza 429. The results of this study may improve our understanding of the biochemical basis of resistance to B. fabae in the faba bean [5]. The beneficial effects derived from phenolic compounds have been attributed to their antioxidant activity [6]. Phenolic compounds could be a major determinant of antioxidant potentials of foods [7] and could therefore be a natural source of antioxidants. The antioxidant activity of phenolic compounds is due to their ability to scavenge free radicals, donate hydrogen atoms or electron, or chelate metal cations [8].

The aim of this study was to evaluate shikimic and salicylic acids as chemical elicitors compared with Ridomil MZ as a fungicide on disease incidence (\%), severity (\%) and oxidative enzyme activity as well as phenolic compounds in response to infection of Vicia faba by B. fabae.

\section{Materials and Methods}

The diseased leaves of faba bean plants were collected from different sites covering 6 districts (Sherbin, Meet ghamer, Talkha, Mansoura, Dekernis and Bani Ebaid) belong to Dakahlia Governorate, Nile Delta Egypt. Infected leaves were thoroughly washed in running tap water followed by sterile water. The leaves were cut into small pieces (1-2 $\left.\mathrm{cm}^{2}\right)$ using sterilized scalpel, and immersed in $0.01 \% \mathrm{HgCl}_{2}$ for $1-3$ min. for surface sterilization. Surface sterilized pieces were then rinsed in sterilized water several times to remove the remaining disinfectant solution and dried on sterilized filter papers. Using sterilized forceps, the dried pieces were then transferred into Petri-dishes containing Potato-Dextrose Agar (PDA) medium [ $200 \mathrm{~g}$ potato; $20 \mathrm{~g}$ dextrose and $15 \mathrm{~g}$ Difco purified agar, made up to $1 \mathrm{~L}$ with distilled water, $\mathrm{pH}$ was adjusted to 6.1] supplemented with broad-spectrum antibacterial agent

*Corresponding author: Heshmat Aldesuquy, Botany Department, Faculty of Science, Mansoura University, Egypt, Fax:+2- 050-2246254; E-mail: heshmat-aldesuquy@hotmail.com

Received November 17, 2014; Accepted February 21, 2015; Published February 25,2015

Citation: Aldesuquy H, Baka Z, Alazab N (2015) Shikimic and Salicylic Acids Induced Resistance in Faba Bean Plants against Chocolate Spot Disease. J Plant Pathol Microb 6: 257. doi:10.4172/2157-7471.1000257

Copyright: $\odot 2015$ Aldesuquy $\mathrm{H}$, et al. This is an open-access article distributed under the terms of the Creative Commons Attribution License, which permits unrestricted use, distribution, and reproduction in any medium, provided the original author and source are credited. 
(streptomycin sulphate, $200 \mathrm{ppm}$ ). The dishes were then incubated at $20^{\circ} \mathrm{C}+2$ for $7-10$ days and checked for microbial growth two days after inoculation. Purification of the resulting isolates was done by using single spore technique to obtain them in pure cultures [9]. Pure cultures of the isolated fungus were identified according to the cultural characteristics, morphological and microscopic features (mycelia development and spore formation) as described by Ellis [10]. Stock cultures were stored on PDA medium under sterile mineral oil at $4^{\circ} \mathrm{C}$.

\section{Pathogenicity test}

Pathogenicity test was carried out on healthy faba bean plants to determine the pathogenic potentialities of Botrytis fabae isolates, which were isolated from different sites. The most aggressive isolate was used throughout this investigation. Artficial inoculation with conidial concentration of $40 \times 10^{4}$ spore's $\mathrm{ml}^{-1}$ was used to spray plants.

\section{Inoculum preparation}

The isolated purified fungus was grown on faba bean-sucrosesodium chloride- agar (FSSA) medium [100 $\mathrm{ml}$ faba bean extract, 20 g sucrose, $20 \mathrm{~g}$ sodium chloride and $20 \mathrm{~g}$ agar dissolved in one liter of distilled water] as proposed by Leach and Moore [11]. The medium was autoclaved and poured into sterilized petri-dishes. Plates were inoculated with 5 days old discs, $6 \mathrm{~mm}$ in diameter, of the isolated fungus grown on PDA medium. Plates were then incubated at $20^{\circ} \mathrm{C}+2$ for 12 days [12] under light regime of UV and normal fluorescent $(12 \mathrm{hr} / 12 \mathrm{hr}$ ) to enhance sporulation. Conidia were harvested using a camel-hair brush and $10 \mathrm{ml}$ of sterilized water for each plate. Conidial concentration was estimated using a haemocytometer and adjusted to about $40 \times 10^{4}$ spore's $\mathrm{ml}^{-1}$.

\section{Artificial inoculation}

Seeds of faba bean susceptible cultivar (Giza 429) were sown in plastic pots ( $35 \mathrm{~cm}$ in diameter) containing $12-13 \mathrm{~kg}$ clay: sand $(2: 1$, v/v) soil. Five seeds were sown in each pot; plants were left to grow and irrigated with normal tap water when necessary. After 45 days, the intact plants were sprayed with the spore suspension of the pathogen and covered with polyethylene bags to maintain enough humidity around the plants. Control plants were sprayed with sterilized water. All pots were kept in a glass house under natural conditions. Disease assessment was recorded after 10 days of microbial spraying.

\section{Disease assessment}

The disease severity (DS) was recorded according to the disease index which based on the standard scale of Gondran [13] as follows:

Disease severity (\%) was calculated using the equation adopted by Hanounik [14]:

$\%$ disease severity $=\frac{(\mathrm{n} \mathrm{x} \mathrm{v})}{\mathrm{gN}} \times 100$

Where: $\mathrm{n}=$ number of plants in every sequence $(\mathrm{v})$

$\mathrm{N}=$ total number of examined plants.

$\mathrm{g}=$ maximum disease grade.

Then efficacy percentage (E\%) of each treatment in reducing disease, severity percentage of faba bean was assessed according to the equation adapted by Rewal and Jhooty [15] as follow:

$\mathrm{E} \%=\%$ disease severity in control $-\%$ disease severity in treatmen $\%$ Disease severity in control

\section{Effect of phenolic compounds on the linear growth of Botrytis fabae}

Salicylic acid, shikimic acid or their interaction were used to study their effects on the linear growth of B. fabae on agar plates. These phenolic compounds were incorporated in PDA medium at concentration of $0.4 \mathrm{mM}$ for shikimic acid and $0.7 \mathrm{mM}$ for salicylic acid by adding the appropriate amount of each substance aseptically to the melted PDA medium just before solidification. Plates containing 20 $\mathrm{ml}$ of the medium for each treatment were prepared. Disks $(1.2 \mathrm{~cm}$ in diameter) taken from the growing edge of 5- day-old colony of $B$. fabae were used to inoculate the prepared plates. For each treatment, five replicates (plates) were used. The plates were incubated at $20^{\circ} \mathrm{C}+2$ for 6 days. The linear growth of $B$. fabae in each treatment was measured after 2, 4 and 6 days of inoculation. Linear growth was measured in $\mathrm{cm}$ by taking the average of two perpendicular diameters. The percentage of inhibition (I\%) was calculated according to Tops and Wain equation [16] as follows:

$$
\mathrm{I} \%=(\mathrm{A}-\mathrm{B}) / \mathrm{A} \times 100
$$

Where: $\mathrm{I} \%=$ Percentage of inhibition.

$\mathrm{A}=$ Mean diameter of growth in the control.

$\mathrm{B}=$ Mean diameter of growth in treatment.

\section{Planting and growth conditions}

Seeds of faba bean (Vicia fabae L.) susceptible $\left[\mathrm{G}_{429}\right]$ were surface sterilized in $0.01 \%$ mercuric chloride for $3 \mathrm{~min}$., subsequently rinsed with sterilized water several times. Sterilized seeds were divided into 4 sets. Seeds of the $1^{\text {st }}, 2^{\text {nd }}, 3^{\text {rd }}$ and $4^{\text {th }}$ set were soaked in distilled water, $0.4 \mathrm{mM}$ Shikimic Acid (SH), $0.7 \mathrm{mM}$ Salicylic Acid (SA) and Shikimic Acid+Salicylic Acid (SH+SA), respectively, for $12 \mathrm{hrs}$. Seeds of each set were planted in plastic pots (5 seeds per pot) filled with $12-13 \mathrm{~kg}$ mixed soil ( 2 clay: 1 sand, $v / v)$. All plants were watered regularly to near field capacity with tap water. Plants were maintained under natural conditions (mean day temperature $22^{\circ} \mathrm{C}$, night temperature $18^{\circ} \mathrm{C}$ and $16 \mathrm{hr}$. photo period). Forty five days later from planting, faba bean plants were inoculated with a spore suspension $\left(40 \times 10^{4}\right.$ spores $\left.\mathrm{ml}^{-1}\right)$ of B. fabae. Untreated plants (control) were sprayed with sterilized water at the same time. Chemical fungicide Ridomil MZ at the rate of (250 $\mathrm{g} / 100 \mathrm{~L}$ ) was applied as spray treatments four times at 15-day intervals.

The experimental design can be summarized as follows:

1- Uninoculated treatment (control) (Cont)

2- B. fabae treatment (pathogen) (P)

3- Shikimic acid treatment (SH)

4- Shikimic acid + B. fabae treatment $(\mathrm{SH}+\mathrm{P})$

5- Salicylic acid treatment (SA)

6- Salicylic acid + B. fabae treatment $(\mathrm{SA}+\mathrm{P})$

7- Salicylic acid+Shikimic acid treatment $(\mathrm{SA}+\mathrm{SH})$

8- Salicylic acid+Shikimic acid + B. fabae treatment $(\mathrm{SA}+\mathrm{SH}+\mathrm{P})$

9-Fungicide (Ridomil MZ) (F)

10-Fungicide $+B$. fabae treatment $(\mathrm{F}+\mathrm{P})$

Samples from the $3^{\text {rd }}$ compound leaf were harvested after 10 weeks from planting for measurements of enzymes activity and phenolic compounds. 


\section{Enzymes activity}

Estimation of peroxidase activity (POD): $0.5 \mathrm{~g}$ of the leaf material was homogenized in a mortar with $30-40 \mathrm{ml}$ of $(0.02 \mathrm{M})$ phosphate buffer $(\mathrm{pH} 7)$ then filtered through cheese cloth and centrifuged at 2000 $\mathrm{rpm}$ for $10 \mathrm{~min}$ then the extract was made up to $100 \mathrm{ml}$ with the buffer. All operations were carried out at $4^{\circ} \mathrm{C}$. Peroxidase activity was assayed according to the methods adopted by Devi [17].

Estimation of polyphenol oxidase activity (PPO): The extract was prepared by using the method suggested for the peroxidase. Polyphenol oxidase activity was assayed as the increase in absorbance at $420 \mathrm{~nm}$ due to the formation of purpurogallin [17]

Estimation of phenylalanine ammonia lyase activity (PAL): $0.5 \mathrm{~g}$ of the leaves was homogenized in a mortar with $5 \mathrm{ml}$ cold $(25$ $\mathrm{mM}$ ) borate buffer ( $\mathrm{pH} 8.8)$ containing $5 \mathrm{mM}$ mercaptoethanol (0.4 $\left.\mathrm{ml} \mathrm{L}^{-1}\right)$. The homogenate was centrifuged in a refrigerated centrifuge at $12,000 \mathrm{rpm}$ for $20 \mathrm{~min}$. The supernatant served as enzyme extract. All operations were carried out at $4^{\circ} \mathrm{C}$. Phenylalanine ammonia lyase activity was determined according to Brueske [18].

\section{Estimation of total phenols}

Total phenols estimation was carried out with folin ciocalteau reagent according to the method described by Malik and Singh [19].

Estimation of salicylic acid and shikimic acid: The salicylic acid and shikimic acid as phenolic compounds were extracted according to Tomas-Barberan et al. [20] with some modifications. Five gram of leaves was homogenized in a Poltroon $(2 \mathrm{~min}$ on ice) with $10 \mathrm{~mL}$ of extraction solution (water/methanol 2:8 containing $2 \mathrm{mM} \mathrm{NaF}$ to inactivate polyphenol oxidases and prevent phenolic degradation due to browning). Homogenates were kept in ice until centrifuged (11500 rpm, $15 \mathrm{~min}, 2-5^{\circ} \mathrm{C}$ ); the supernatant was recovered carefully to prevent contamination with the pellet, and the volume was measured. Samples were run through a HPLC system (Agilent 1100 series) coupled with UV-Vis detector (G1315B) and G1322A DEGASSER. Sample injections of $20 \mu \mathrm{L}$ were made from an Agilent 1100 Series auto-sampler; the chromatographic separations were performed on ZORBAX-EclipseXDB- $C_{18}$ column $(4.6 \times 250 \mathrm{~mm}$, particle size $5 \mu \mathrm{m})$. Optimum efficiency of separation was obtained using acetonitrile (solvent A), and the flow rate of methanol (solvent B) with flow rate 1 $\mathrm{ml} / \mathrm{min}$. Ten min of equilibration is required before the next injection. All the stock solutions were prepared in $\mathrm{Me} \mathrm{OH}: \mathrm{H}_{2} \mathrm{O} 80 / 20$ and the standard dilutions with deionized water.

\section{Statistical analysis}

A test for significant differences between means at $\mathrm{P} \leq 0.05$ was performed using least significant difference (LSD) test [21] by SPSS program.

\section{Results and Discussion}

Because of hazards of pesticides in general, and fungicides in specific, on public health and environmental balance, moreover, faba bean cultural practice modifications using fungicides provided only partial crop protection without attention to subsidiary adverse effects of fungicides on the host plant. Thus, this study was planned to replace the undesirable and unsafe chemical control by a relatively recent direction for faba bean chocolate spot disease control, the so called "induced resistance" which is a promising modern approach with a broad spectrum in plant disease control $[22,23]$. The use of shikimic or salicylic acids and their combination to increase the resistance of infected faba bean plants against $B$. fabae were investigated.
Surveys for faba bean chocolate spot disease covering 6 districts (Sherbin, Meet ghamer, Talkha, Mansoura, Dekernis and Bani Ebaid) belong to Dakahlia Governorate, Nile Delta Egypt were conducted. Out of these surveys, six isolates of the pathogen were obtained and purified using single spore technique. These isolates were identified as B. fabae. All isolates were subjected to pathogenicity tests to determine the most aggressive one. All isolates appeared to have the potency to cause chocolate spot disease, but the isolate (B1) from Sherbin was considered to be the most aggressive one and was selected for further studies (Table 1). Shikimic acid or salicylic acid were found to be the most effective inhibitors for the linear growth of $B$. fabae in vitro than their combination (Table 2). These results were in good agreement with those obtained by many investigators on different pathogens [24,25]. Furthermore, Abd El-Hai et al. [26] showed that salicylic acid at $10 \mathrm{mM}$ alone or in combination with citric acid completely inhibited the linear growth (in vitro) of Rhizoctonia solani and Macrophomina phasolina the causal pathogens of damping-off and charcoal rot diseases of sunflower plant, respectively.

It was also reported that salicylic acid as an allelochemical greatly inhibited Fusarium oxysporum f. sp. niveum (the causal pathogen of water melon Fusarium wilt) growth and conidia formation and germination, though stimulated mycotoxin production and activities of hydrolytic enzymes by F. oxysporum f. sp. niveum [27].

Phenolic are well-known antifungal, antibacterial and antiviral compounds occurring in plants [28]. Cowan [29] explained the mechanisms thought to be responsible for the phenolic toxicity to microorganisms on the basis of enzyme inhibition by the oxidized compounds, possibly through reaction with sulfhydryl groups or through more nonspecific interactions with the proteins. The site(s) and number of hydroxyl groups on the phenol compound are thought to be related to their relative toxicity to microorganisms, with evidence that increased hydroxylation results in increased toxicity. In addition, some investigators have found that the more highly oxidized phenols the more inhibitory effect to a pathogen [30].

The antimicrobial action of salicylic acid may be due to inhibition of functions of several enzymes by oxidized compounds, dissolved membrane lipids and interfere with membrane functions including transport of nutrients and interferes with proteins, RNA and DNA synthesis [31].

The role of salicylic acid is well-known at the beginning of defense responses against different abiotic and biotic stress [32]. Thus, the tested phenolic compounds (shikimic acid, salicylic acid or their combination) were highly effective in controlling chocolate spot disease incidence and severity when applied as seed treatment before planting more than fungicide which provided only partial crop protection (Table 3). These results are in a close parallelism with those of Hassan et al. [23] who reported that application of chemical inducers such as

\begin{tabular}{|c|c|c|c|}
\hline Isolate & Location & $\begin{array}{c}\text { Disease incidence } \\
\mathbf{( \% )}\end{array}$ & $\begin{array}{c}\text { Disease severity } \\
\mathbf{( \% )}\end{array}$ \\
\hline B1 & Sherbin & 75 & 5 \\
\hline B2 & Meet Ghamer & 65 & 4 \\
\hline B3 & Talkha & 67 & 2 \\
\hline B4 & Mansoura & 54 & 2 \\
\hline B5 & Dekernis & 51 & 2 \\
\hline B6 & Bani Ebaid & 55 & 3 \\
\hline
\end{tabular}

Table 1: Pathogenicity test for the different isolates of $B$. fabae collected from different locations in Dakahlia governorate, Egypt. 
Citation: Aldesuquy H, Baka Z, Alazab N (2015) Shikimic and Salicylic Acids Induced Resistance in Faba Bean Plants against Chocolate Spot Disease. J Plant Pathol Microb 6: 257. doi:10.4172/2157-7471.1000257

Page 4 of 8

\begin{tabular}{|c|c|c|c|c|c|c|c|}
\hline \multirow{3}{*}{ Treatments } & \multicolumn{6}{|c|}{ Days of incubation } & \multirow{3}{*}{ Growth rate (cm/day) } \\
\hline & \multicolumn{2}{|c|}{ 2days } & \multicolumn{2}{|c|}{4 days } & \multicolumn{2}{|c|}{6 days } & \\
\hline & $\begin{array}{c}\text { Colony diameter } \\
(\mathrm{cm})\end{array}$ & \%Inhibition & $\begin{array}{c}\text { Colony diameter } \\
(\mathrm{cm})\end{array}$ & \%Inhibition & $\begin{array}{l}\text { Colony diameter } \\
(\mathrm{cm})\end{array}$ & \%Inhibition & \\
\hline Control & 3.35 & 0.00 & 6.55 & 0.00 & 8.88 & 0.00 & 1.38 \\
\hline Shikimic acid (SH) & 2.70 & 19.40 & 3.40 & 48.14 & 5.5 & 38.06 & 0.70 \\
\hline Salicylic acid (SA) & 2.40 & 28.35 & 3.30 & 49.67 & 5.2 & 41.44 & 0.70 \\
\hline SH+SA & 3.10 & 7.46 & 3.55 & 45.85 & 6.8 & 23.42 & 0.93 \\
\hline LSD at $P \leq 0.05$ & 0.46 & - & 0.41 & - & 0.56 & - & 0.19 \\
\hline
\end{tabular}

Each value represents the mean of 5 replicates.

Table 2: Effect of shikimic acid, salicylic acid and their combination on the linear growth, inhibition (\%) and growth rate (cm/day) of $B$. fabae after 2 , 4 and 6 days of incubation.

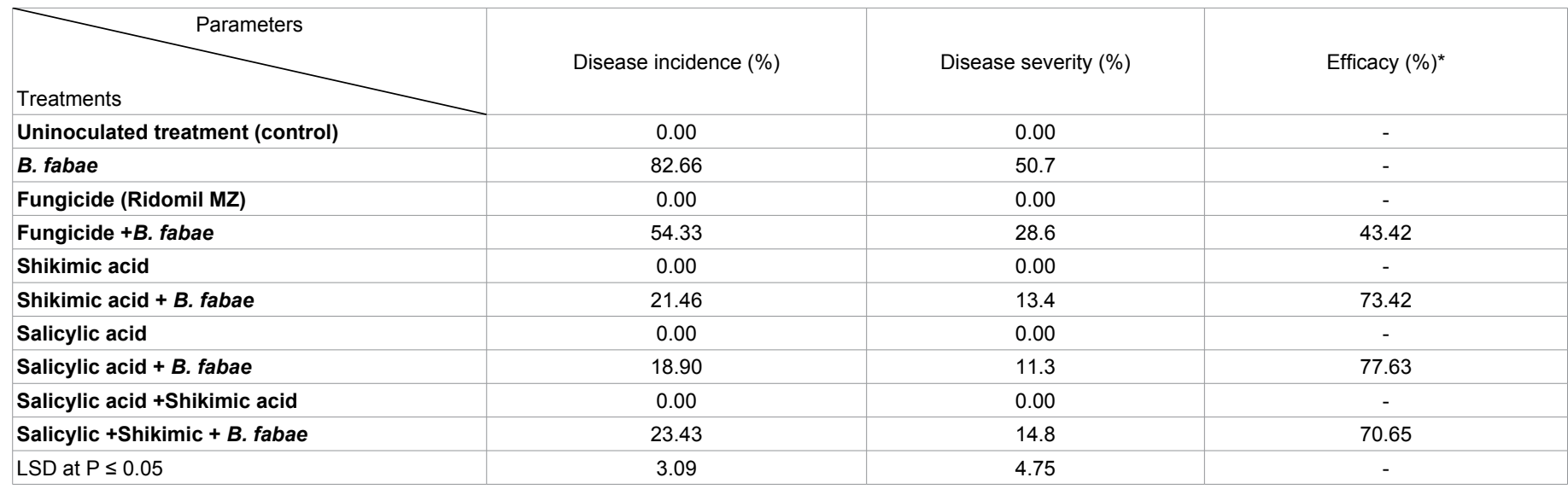

${ }^{*}$ Efficacy $\%=\frac{\% \text { disease severity in control }-\% \text { disease severity in treatmen }}{\% \text { Disease severity in control }}$

Table 3: Effect of shikimic acid, salicylic acid and their combination on Disease incidence (\%), disease severity and efficacy (\%) of faba bean plants infected with chocolate spot disease.

salicylic acid at two different concentrations can decrease the disease severity of chocolate spot disease in faba bean plants. Furthermore, Abbas et al. [33] showed that application of salicylic acid as a foliar spray to faba bean plant led to reduction in the incidence of chocolate spot disease caused by Botrytis fabae.

El-Hendawy et al. [34] noticed that presoaking of faba bean seeds in chemical inducers such as salicylic acid give the highest reduction in disease severity of chocolate spot at different periods of inoculation. In addition, Ghazanfar et al. [35] found that $1.5 \mathrm{mM}$ salicylic acid caused a $56.8 \%$ disease reduction of chickpea blight disease caused by Ascochyta rabiei. Hadi and Balali [36] recorded similar results in case of potato plants infected with Rhizoctonia solani.

The effect of salicylic acid to induce resistance in groundnut plants against Alternaria alternata was investigated by Chitra et al. [37]. Foliage spray of $2 \mathrm{mM}$ salicylic acid significantly reduced (40.3\%) leaf blight of onion caused by Stemphylium vesicarium under greenhouse conditions $15 \mathrm{~d}$ after inoculation [38]. The ability of the four chemicals salicylic acid, sodium salt of salicylic acid, isonicotinic acid, and DL$\beta$-amino- $n$ butyric acid, as well as the yeast antagonist Cryptococcus flavescens were evaluated against Fusarium head blight of wheat under greenhouse conditions showing that sodium salicylate $(\mathrm{NaSA})$ and 2,6-dichloroisonicotinic acid (INA) at $10 \mathrm{mM}$ significantly reduced Fusarium Head Blight (FHB) severity compared with the non-treated disease control $3 \mathrm{~d}$ prior to challenge with the pathogen [39]. The significant trait of the disease resistance inducer is that it persists longer in the host by increasing its biochemical constituents. Under infection with Phytophthora cryptogea, applying a higher concentration of salicylic acid at $8 \mathrm{~g} \mathrm{~L}^{-1}$ to potato plants caused more vigorous growth than in the control [40]. Furthermore, a higher accumulation of salicylic acid at the infection site was found, which may be attributable to transcriptional activation of $\mathrm{PR}$ genes in the inoculated and uninoculated leaves [41].

The superiority effect of fungicide in reducing infection may attributed to its toxicity against the pathogen, while the positive effect of shikimic acid or salicylic acid or their combination may be due to their action as plant defense activators [42].

Salicylic acid has an affinity to bind with the enzymes involved in reactive oxygen species metabolism and in redox homeostasis. Alteration in this homeostasis leads to induction of a defense response in plants [43]. SA also affects the lipid peroxidation, which plays a key role in initiating defense response [44].

Salicylic acid-induced pathway is characterized by the production of a cascade of pathogenesis related proteins. Where, a number of biochemical and physiological changes has been associated with pathogen infection, these include:

1. The production of antifungal chitinases, glucanases and thaumatins, and oxidative enzymes such as PODs, PPOs and lipoxygenases.

2. Low molecular weight compounds with antimicrobial properties (phytoalexins) can also accumulate [45]. 


\section{Cell death and deposition of callose and lignin [46]}

\section{Forming novel proteins [47].}

Phenolic seem to inhibit disease development through different mechanisms involving the inhibition of extracellular fungal enzymes (cellulases, pectinases, lactase, xylanase), inhibition of fungal oxidative phosphorylation, nutrient deprivation (metal complexion, protein insolubilisation), and antioxidant activity in plant tissues [48]. Many phenolic compounds are known to be antimicrobial, function as precursors to structural polymers such as lignin, or serve as signal molecules.

Increase in the activity of the defense enzymes has been reported in plants treated with various biotic and abiotic inducers of resistance [49]. The data presented in Table 4 indicated that presoaking of faba bean seeds in phenolic compounds led to an increase in the activity of oxidative enzymes (POD, $\mathrm{PPO}$ ) in plant leaves than untreated infected plants. These results are parallel to those obtained by El-Hendawy et al. [34] who stated that there was a significant increase in the activity of POD and PPO after treatment of wheat, anise, sugar beet and fava bean plants with salicylic acid. This might be due to the role of salicylic acid in generation of the oxidative burst by inducing a rapid transient generation of $\mathrm{O}_{2}^{-}$which is responsible for regulation of POD activity [50].

Activities of oxidative enzymes in any infected plant tissues are known to contribute to disease resistance mechanisms through the oxidation of phenols [51]. Nawar and Kuti [52] mentioned that, POD activity in leaves of resistant cultivars of broad bean infected with $B$. fabae was 10 times higher than that of susceptible cultivars and eight times higher in uninfected leaves of the resistant than the susceptible cultivars. PODs are ionically bound to the cell walls and are involved in the polymerization of phenylpropanoid lignin precursors [53]. Oxidation of PODs makes the cell wall more mechanically rigid by cross-linking matrix polysaccharide and glycoprotein molecules, thus modifying the mechanical properties of the cell wall. In general, cross linking of matrix polysaccharides in cell walls are also likely to inhibit cell wall degrading enzymes of the pathogen.

POD causes the oxidation of a wide variety of substrates, using $\mathrm{H}_{2} \mathrm{O}_{2}$, such as phenols which play a considerable role in lignin synthesis [54]. Tarrad et al. [51] reported that the increase in POD activity enhanced lignification in response to chocolate spot disease, which may restrict fungal penetration. Another supportive suggestion was made by Nawar

\begin{tabular}{|c|c|c|c|}
\hline Treatments & $\begin{array}{l}\text { POD } \\
\left(\mathrm{U} \mathrm{min}^{-1} \mathrm{~g}^{-1}\right. \\
\text { fresh wt })\end{array}$ & $\begin{array}{l}\text { PPO } \\
\left(\mathrm{U} \text { min }^{-1}\right. \\
\mathrm{g}^{-1} \\
\text { fresh wt })\end{array}$ & $\begin{array}{c}\text { PAL } \\
\text { ( } \mu \text { mole t-cinnamic } \\
\text { acid } \mathrm{hr}^{-1} \mathrm{~g}^{-1} \text { fresh } \\
\mathrm{wt})\end{array}$ \\
\hline Uninoculated treatment (control) & 17.56 & 1.46 & 397.41 \\
\hline B. fabae & 25.28 & 2.51 & 588.37 \\
\hline Fungicide (Ridomil MZ) & 17.19 & 1.38 & 391.73 \\
\hline Fungicide $+B$. fabae & 23.90 & 2.46 & 584.49 \\
\hline Shikimic acid & 19.86 & 1.97 & 433.33 \\
\hline Shikimic acid + B. fabae & 31.41 & 2.93 & 632.29 \\
\hline Salicylic acid & 22.74 & 2.14 & 442.89 \\
\hline Salicylic acid + B. fabae & 32.82 & 3.08 & 666.15 \\
\hline Salicylic acid +Shikimic acid & 17.40 & 1.50 & 396.12 \\
\hline Salicylic +Shikimic + B. fabae & 27.33 & 2.81 & 628.68 \\
\hline LSD at $P \leq 0.05$ & 0.57 & 0.08 & 2.69 \\
\hline
\end{tabular}

Table 4: Effect of shikimic acid, salicylic acid and their combination on peroxidase (POD), polyphenol (PPO) and phenylalanine ammonia lyase (PAL) enzymes activities in the shoot of faba bean plants infected with chocolate spot disease. and Kuti [53] who stated that, an increase in POD activity is considered to be a preliminary indicator for resistance of broad beans to chocolate spot disease. These findings indicate a positive relationship between resistance and POD activity.

PODs have roles in both the production and scavenging of reactive oxygen species [55]. Some PODs are responsible for the production of $\mathrm{H}_{2} \mathrm{O}_{2}$ [55]. $\mathrm{H}_{2} \mathrm{O}_{2}$ produced by these PODs might serve as the substrate for other PODs or act as an antimicrobial agent and signals to trigger self-defense responses like hypersensitive reaction [56,57].

The accumulation of these enzymes is dependent on the fungal growth; the newly synthesized polyphenol and their oxidized products may limit the fungal activity on the plant tissues. POD present in plant tissues participate in the biosynthesis of ethylene which acts as an inducer for the resistance by stimulating the production of phytoalexins in some plants [58].

Polyphenol oxidase generally catalyzes the oxidation of phenolic compounds to quinones (antimicrobial compounds) using molecular oxygen as an electron acceptor which are toxic to the invading pathogens and pests [59]. PPOs are suggested to be indirectly involved in IAA biosynthesis because the $\mathrm{O}$-quinones produced can react with tryptophan to form indole-3-acetic acid [60]. POD and PPO are important in the defense mechanism against pathogens, through its role in the oxidation of phenolic compounds to quinones [61]; the quinones formed may act in several ways leading to the protection of plants through:

(1) Their high capacity for reacting with other cellular compounds, quinones can limit the development of diseases at the infected sites; accelerating the cellular death of cells close to the infection site; preventing the advance of infection and/or by generating a toxic environment which will inhibit the growth of the pathogen inside the cells.

(2) Their ability to alkylate proteins, mainly by becoming covalently linked to amino acids susceptible to alkylation, such as lysine, histidine, cysteine and methionine, thereby reducing the bioavailability of such proteins.

(3) Their ability to react with other phenolic compounds; increasing the formation of polymers, covalent linkages and condensation with more proteins, leading to additional barriers that can prevent the pathogens from entering the cell.

Lamb and Dixon [62] reported that salicylic acid causes an increase in the accumulation of $\mathrm{H}_{2} \mathrm{O}_{2}$ in plant tissues which plays a key role in initiating hypersensitive responses and providing SAR against pathogenic microbes. Salicylic acid is found to alter the activity of a mitochondrial enzyme, alternative oxidase, which mediates the oxidation of ubiquinol/ubiquinone pool and reduction of oxygen to water, without the synthesis of ATP in mitochondria and this altered activity of enzyme alternative oxidase affects the ROS levels in mitochondria and in turn induces an antiviral defense response in plants [63].

The data in Table 4 clearly show that shikimic acid accelerate the production of the defense enzymes (POD and PPO) which increase the oxidation of phenol to its corresponding quinones which have a significant role in the rigidity of cell wall by increasing the lignification. Furthermore, shikimic acid acts as a precursor of lignin biosynthesis [64].

Phenylalanine Ammonia-Lyase (PAL) is a crucial enzyme in the 
phenylpropanoid pathway, catalyzing the formation of trans-cinnamic acid via the L-deamination of phenylalanine. It is commonly considered the principal enzyme in the biosynthesis of phenolic compounds [65]. PAL activity in plant tissue may rapidly change under the influence of various factors, e.g. pathogen attack and treatment with elicitors [66]. The present results showed that, the activity of PAL was increased with infection by B. fabae (Table 4). Furthermore, seed presoaking in phenolic compounds caused additional increase in the PAL activity, which is in agreement with the finding of El-Khallal [67], who showed that PAL activity significantly increased in tomato plants treated with salicylic acid in response to Fusarium oxysporum.

The obvious increase in PAL activity as a result of shikimic acid application may probably due to shikimic acid acts as a precursor for major of phenolic compounds within plant tissues which consequently increase the production of PAL within the plant tissues especially the infected ones.

Phenols have been recorded to offer resistance to diseases and pests in plants, and grains containing high amount of polyphenols are resistant to several plant diseases [19]. There were many researchers established that higher level of phenolic content was positively proportional to the degree of plant resistance against various fungal diseases [38]. Total phenols, salicylic and shikimic acids contents were progressively increased with infection (Table 5). Moreover, shikimic acid, salicylic acid and their combination induced additional increase in the endogenous total phenols, salicylic and shikimic acids in healthy and infected plant tissues. These findings are in a good accordance with those of El-Hendawy et al [34] who found that faba bean plants treated with salicylic acid either foliar spray or seed soaking showed the maximum accumulation of total phenols, as compared with the untreated control ones. Furthermore, similar results were obtained by El-Khallal [67]; Abou-Elyousr et al. [38].They reported that there is a positive correlation between the application of phenolic compounds and the increase in PAL activity was found, which in turn led to the accumulation of total phenolic. In addition, Abd El-Hai et al. [26] reported that the total phenols content was increased significantly in sunflower plant infected with damping-off and charcoal rot disease under application of salicylic acid treatment.

The increased level of phenolic provides an adequate substrate to oxidative reactions catalyzed by PPO and/or POD that, consuming oxygen and producing fungi toxic quinones, make the medium unfavorable to the further development of pathogens. Antifungal

\begin{tabular}{|c|c|c|c|}
\hline Treatments & $\begin{array}{c}\text { Total } \\
\text { phenols } \\
\left(\mu \mathrm{g} \mathrm{g}^{-1} \text { fresh }\right. \\
\text { wt })\end{array}$ & $\begin{array}{c}\text { Salicylic } \\
\text { acid } \\
\text { (ng g }{ }^{-1} \text { fresh } \\
\text { wt) }\end{array}$ & $\begin{array}{l}\text { Shikimic acid } \\
\left(\mathrm{ng} \mathrm{g}^{-1} \text { fresh wt) }\right.\end{array}$ \\
\hline Uninoculated treatment (control) & 11.41 & 46.08 & 117.46 \\
\hline B. fabae & 13.09 & 49.41 & 129.66 \\
\hline Fungicide (Ridomil MZ) & 12.05 & 47.93 & 121.89 \\
\hline Fungicide + B. fabae & 13.76 & 50.71 & 138.34 \\
\hline Shikimic acid & 15.97 & 63.57 & 156.88 \\
\hline Shikimic acid + B. fabae & 18.53 & 67.64 & 170.56 \\
\hline Salicylic acid & 17.67 & 71.18 & 171.24 \\
\hline Salicylic acid + B. fabae & 19.90 & 75.82 & 180.54 \\
\hline Salicylic acid +Shikimic acid & 14.20 & 52.19 & 131.22 \\
\hline Salicylic +Shikimic + B. fabae & 15.83 & 57.61 & 164.42 \\
\hline LSD at $P \leq 0.05$ & 1.42 & 1.85 & 1.41 \\
\hline
\end{tabular}

Table 5: Effect of shikimic acid, salicylic acid and their combination on total phenols, salicylic acid and shikimic acid contents in the shoot of faba bean plants infected with chocolate spot disease. activity of oxidized phenolic may also be related to the necrotic reaction, e.g. the oxidative polymerization involving phenolic compounds, amino acids and proteins that yields brown melanin. This reaction results in the formation of an impermeable barrier to pathogenesis by plant parasites, and in a decrease of nutrients essential to the fungal development [68]. It is well known that synthesis of phenols occurs as an early response of plants to attempt infection by pathogens, as antimicrobial compounds, signal molecules, and cell wall strengthening components [69]. It was found in the present study that the activity of POD and PPO enzymes were higher in treated leaves, these enzymes act by oxidation of phenolic compounds to quinones that have toxicity 100 times more than the corresponding phenolic compounds [70]. Phenols are essential for the biosynthesis of lignin, which is considered an important structure component of plant cell walls [71]. Antibiotic phenols have the ability to bind to some proteins in vitro, forming soluble and insoluble complexes [72]. These phenolicprotein interactions are thought to be, in part, responsible for putative function of phenolic as plant defense compounds. However, several phenolic compounds are directly antifungal in their free state as well [73].

In this study, the dramatic increase in total phenols of faba bean plants (Table 5) as a result of infection by B. fabae are in conformity with the finding of Petkovsek et al. [74] who found that the level of total phenolic in the infected tissue was 1.3-2.4 times higher than in the healthy leaves and fruit of apple plant. The production and accumulation of phenolic occurs in healthy plant cells surrounding wounded or infected cells, and they are stimulated by alarm substances produced and released by the damaged cells and diffusing into the adjacent healthy cells. Therefore, the activity of many phenol-oxidizing enzymes is generally higher in the infected tissue than in the uninfected tissue of healthy plants. Changes at the phenolic level can play a role in the protection of the plant.

In the present study, endogenous salicylic acid increased in faba bean plants due to inoculation of $B$. fabae (Table 5). This increment of salicylic acid concentration in the leaf tissues might have contributed for enhanced resistance to the pathogen as was evidenced by significantly reduced chocolate spot appearance. These results agree with those of Mandal et al. [75] who noticed that the content of endogenous salicylic acid was increased significantly in tomato plants treated with salicylic acid as a foliar spray and through root treatment under Fusarium oxysporum infection. Salicylic acid accumulation due to the pathogen or phenolic compounds application was shown to result from the enhanced activity of PAL [76]. Chen et al. [77] proposed that high activity of PAL in salicylic acid -treated plants indicated that the development of acquired resistance by salicylic acid may be attributed at least partly, to the salicylic acid induced PAL gene expression and activation. Where, salicylic acid could activate PAL by enhancing the accumulation of PAL mRNA, the synthesis of new PAL protein and its activity and consequently enhances the accumulation of phenylpropanoids such as phenolic acids. In this respect, results suggested that phenyl propanoid compounds are more rapidly synthesized in leaves of infected faba bean plants especially treated with phenolic compounds.

The data showed that both the PAL activity and phenolic compounds accumulations were enhanced dramatically after the phenolic compounds treatments, indicating that PAL is the key enzyme in regulating the salicylic acid elicited phenolic acid accumulations in faba bean plants. These results are in good agreement with those obtained by Dong et al. [78]. Chitra et al. [37] revealed that foliar 
applications of salicylic acid induced in PAL, POD and PPO activities and caused an increase in phenolic content of groundnut plants upon challenge inoculation with Alternaria alternata.

\section{Conclusion}

The application of shikimic acid may act in the same manner of salicylic acid in enhancing the production of PAL and endogenous phenolic compounds (Total phenols, salicylic and shikimic acids) but, the lack of data about the effect of shikimic acid on different infected plant tissues as the authors are aware makes this postulation not decisive. Therefore, the prospect for the future is good for the application of phenolic compounds because of the lessened availability of fungicides to protect crop plants. Moreover, we recommended the application of such phenolic compounds separately because of the insignificance effect of their combination which may be attributed to it's over dose on the plant. In addition, the most effective treatment in enhancement faba bean resistance against $B$ fabae infection was salicylic acid.

\section{References}

1. El-Sayed F, Nakoul H, Williams $P$ (1982) Distribution of protein content in the collection of faba bean (vicia faba L.). FABIS 5: 37-41.

2. Mazen MMM (2004) Resistance induction against disease of faba bean crop. Ph.D. Thesis, Fac. Agric., Suez Canal Universityp.159.

3. Almagro L, Gómez Ros LV, Belchi-Navarro S, Bru R, Ros Barceló A, et al (2009) Class III peroxidases in plant defence reactions. J Exp Bot 60: 377-390.

4. Mayer AM (2006) Polyphenol oxidases in plants and fungi: going places? A review. Phytochemistry 67: 2318-2331.

5. Mohamed AM, Saleh AA, Monira RA, Abeer R, Abd El-Aziz M (2012) Biochemical screening of chocolate spot disease on faba bean caused by Botrytis fabae. African J Microbiol Res 6: 6122-6129.

6. Heim KE, Tagliaferro AR, Bobilya DJ (2002) Flavonoid antioxidants: chemistry, metabolism and structure-activity relationships. J Nutr Biochem 13: 572-584.

7. Parr AJ, Bolwell GP (2000) Phenols in the plant and in man. The potential for possible nutritional enhancement of the diet by modifying the phenols content or profile. J Sci Food Agric 80: 985-1012.

8. Amarowicz R, Peg RB, Rahimi-Moghaddam P, Barl B, Weil JA (2004) Freeradical scavenging capacity and antioxidant activity of selected plant species from the Canadian prairies. Food Chem 84: 551-562.

9. Shabana YM (1987) Biological control of water weeds by using plant pathogens. M.Sc. Thesis, Fac. Agric Mansoura Univ Egypt. pp. 78

10. Ellis MB (1971) Dematiaceous Hyphomycetes.Common wealth Mycological Institute.Kew. Surrey, England.

11. Leach R, Moore KG (1966) Sporulation of Botrytis fabae on agar culture. Trans Brit Mycol Soc 49: 593-601.

12. Last FT, Hamley RE (1956) A local lesion technique for measuring the infectivity of conidia of Botrytis fabae Sard Ann Appl Biol 44: 410-418.

13. Gondran J (1986) Resistance de la vase de narbonne et de la Feverole a Botrytis fabae V. eme Journee de phytiatrie de phytoarmacie circum. Mediterrancennes. 15-20 Mai, Rebat, Maroc. 1977; [C.F. Fabis Newsletter N 16: 46-52]

14. Hanounik SB (1986) Screening Techniques for Disease Resistance in faba bean. International Centre for Agricultural Research in the Dry Areas (ICARDA). Aleppo, Syria, pp.59.

15. Real HS, Hoot JS (1985) Differential response of wheat varieties to systemic fungicides applied to Stillage triticale (Pers.). Roster Indian J Agaric Sic 55: $548-549$

16. Topps J, Hand Win RL (1957) Investigation of fungicides. III. The fungi toxicity and 5-alkyl salicylic anal ide and para chloroanilines. Ann Appl Biol 45: 506511.

17. Devi $P$ (2002) Principles and methods in plant molecular biology, biochemistry and genetics. Agrobios Ind 41: 57-59.
18. Brueske $\mathrm{CH}$ (1980) Phenylalanine ammonia-lyase activity in tomato roots infected and resistant to the root-knot nematode, Meloidogyne incognita. Physiol Plant Pathol 16: 409-414.

19. Malik CP, Singh MB (1980) Estimation of Total Phenols in Plant Enzymology and Histo-enzymology. Kalyani Publishers, New Delhi.

20. Tomás-Barberán FA, Gil MI, Cremin P, Waterhouse AL, Hess-Pierce $B$, et al. (2001) HPLC-DAD-ESIMS analysis of phenolic compounds in nectarines peaches, and plums. J Agric Food Chem 49: 4748-4760.

21. Snedecor GW, Cochran WG (1976) Statistical Methods. 6th ed. Oxoford IBH Publishing Co. New Delhi.

22. Reglinski T, Whitaker G, Cooney JM, Taylor JT, Pooles PR, et al. (2001) Systemic acquired resistance to Sclerotinia sclerotiorum in kiwi fruit vines. Physiol Mol Plant Pathol 58: 111-118.

23. Hassan MEM, Abd El-Rahman SS, El-Abbasi IH, Mikhail MS (2006) Inducing resistance against faba bean chocolate spot disease. Egypt J Phytopathol 34 69-79.

24. Shahda WT (2000) The use of antioxidants for control of tomato damping off. Alex J Agric Res 45: 307-316.

25. Shabana YM, Abdel-Fattah GM, Ismail AE, Rashad YM (2008) Control of brown spot pathogen of rice (Bipolaris oryzae) using some phenolic antioxidants. Braz J Microbiol 39: 438-444.

26. AbdEl-Hai KM, El-Metwally MA, El-Baz SM, Zeid AM (2009) The use of antioxidants and microelements for controlling damping-off caused by Rhizoctonia solani and charcoal rot caused by Macrophomina phasoliana on sun flower. Plant Pathol J 8: 79-89.

27. Wu HS, Raza W, Fan JQ, Sun YG, Bao W, et al. (2008) Antibiotic effect of exogenously applied salicylic acid on in vitro soilborne pathogen, Fusarium oxysporum f.sp.niveum. Chemosphere 74: 45-50.

28. Hayat S, Ahmad A (2007) Salicylic Acid: A Plant Hormone. Springer, Dordrecht, Netherlands.

29. Cowan MM (1999) Plant products as antimicrobial agents. Clin Microbiol Rev 12: $564-582$

30. Scalbert A (1991) Antimicrobial properties of tannins. Phytochem 30: 38753883.

31. Nesci A, Rodriguez M, Etcheverry M (2003) Control of Aspergillus growth and aflatoxin production using antioxidants at different conditions of water activity and pH. J Appl Microbiol 95: 279-287.

32. Catinot J, Buchala A, Abou-Mansour E, Métraux JP (2008) Salicylic acid production in response to biotic and abiotic stress depends on isochorismate in Nicotiana benthamiana. FEBS Lett 582: 473-478.

33. Abbas EE, Ghoneem KM, Ali AA, El-baz SM (2006) Yield maximization and chocolate spot control of some faba bean cultivars by antioxidants. J Agric Sci Mansoura Univ 31: 7605-7615.

34. El-Hendawy S, Shaban W, Sakagami JI (2010) Does treating faba bean seeds with chemical inducers simultaneously increase chocolate spot disease resistance and yield under field conditions? Turk J Agric For 34: 475-485.

35. Ghazanfar MU, Wakil W, Sahi ST (2011) Induction of resistance in chickpea (Cicer arietinum L.) against Ascochyta rabiei by applying chemicals and plant extracts. Chil J Agr Res 71: 52-62.

36. Hadi MR, Balali GR (2010) The effect of salicylic acid on the reduction of Rhizoctonia solani damage in the tubers of marfona potato cultivar. Am-Euras J Agric Environ Sci 7: 492-496.

37. Chitra K, Ragupathi N, Dhanalakshmi K, Mareeshwari P, Indra N, et al. (2008) Salicylic acid induced systemic resistant on peanut against Alternaria alternata. Arch Phytopathol Plant Protect 41: 50-56.

38. Abo-Elyousr KAM, Hashem M, Ali EH (2009) Integrated control of cotton root rot disease by mixing fungal biocontrol agents and resistance inducers. Crop Prot 28: 295-301.

39. ZhangY, Tian Z, Xi R, Gao H Qu P (2002) Effect of salicylic acid on phenolics metabolization of Yali pear growing fruits. J Agric Univ Hebei 25: 33-36.

40. Quintanilla P, Brishammar S (1998) Systemic induced resistance to late blight in potato by treatment with salicylic acid and Phytophthora cryptogea. Potato Res 41: 135-142. 
Citation: Aldesuquy H, Baka Z, Alazab N (2015) Shikimic and Salicylic Acids Induced Resistance in Faba Bean Plants against Chocolate Spot Disease. J Plant Pathol Microb 6: 257. doi:10.4172/2157-7471.1000257

41. Durner J, Shah J, Kessig DF (1997) Salicylic acid and disease resistance in plants. Trends Plant Sci 2: 266-274.

42. Ata AA, El-Samman MG, Moursy MA, Mostafa MH (2008) Inducing resistance against rust disease of sugar beet by certain chemical compounds. Egypt $J$ Phytopathol 36: 113-132.

43. Durrant WE, Dong $X$ (2004) Systemic acquired resistance. Annu Rev Phytopathol 42: 185-209.

44. Anderson MD, Chen Z, Klessig DF (1998) Possible involvement of lipid peroxidation in salicylic acid-mediated induction of PR1 gene expression. Phytochem 47: 555-566.

45. Soylu S, Bennett MH (2002) Mansfiels JW. Induction of phytoalexin accumulation in broad bean (Vicia faba L.) cotyledons following treatments with biotic and abiotic elicitors. Turk J Agric 26: 343-348.

46. Green S, Bailey KL, Tewari JP (2001) The infection process of Alternaria cirsinoxia on Canada thistle (Cirsium arvense) and host structural defense responses. Mycol Res 105: 344-351.

47. Myers GA, Grinvalds R, Booth S, Hutton SI, Binks M (2000) Expression of two novel proteins in Chlamydia trachomatis during natural infection. Microb Pathog 29: 63-72.

48. Hammerschmidt R (2005) Phenols and plant-pathogen interactions: The saga continues. Physiol Mol Plant Pathol 66: 77-78.

49. Raghvendra VB, Lokesh S, Govindappa M, Vasanth KT (2007) Dravya as an organic agent for the management of seed borne fungi of sorghum and its role in the induction of defense enzymes. Pes Biochem Physiol 89: 190-197.

50. Rao MV, Paliyath G, Ormrod DP, Murr DP, Watkins CB (1997) Influence of salicylic acid on $\mathrm{H} 2 \mathrm{O} 2$ production, oxidative stress, and $\mathrm{H} 2 \mathrm{O} 2$-metabolizing enzymes. Salicylic acid-mediated oxidative damage requires $\mathrm{H} 2 \mathrm{O} 2$. Plant Physiol 115: 137-149.

51. Tarrad AM, El-Hyatemy YY, Omar SA (1993) Wyerone derivatives and activities of peroxidase and polyphenol oxidase in faba bean leaves as induced by chocolate spot disease. Plant Sci 89: 161-165.

52. Nawar HF, Kuti, JO (2003) Wyerone acid phytoalexin synthesis and peroxidase activity as markers for resistance of broad beans to chocolate spot disease. Phytopathol J 151: 564-570.

53. Cvikrová M, Malá J, Hrubcová M, Eder J (2006) Soluble and cell wall-bound phenolics and lignin in Ascocalyx abietina infected Norway spruces. Plant Sci 170: $563-570$.

54. Goldberg R, Liberman M, Mathieu C, Pierron CM, Catesson AM (1987) Development of epidermal cell wall peroxidase along the bean hypocotyls: Possible involvement in the cell wall stiffening process. J Exp Bot 38: 13781390.

55. Bolwell GP, Bindschedler LV, Blee KA, Butt VS, Davies DR, et al. (2002) The apoplastic oxidative burst in response to biotic stress in plants: a threecomponent system. J Exp Bot 53: 1367-1376.

56. Wojtaszek $P$ (1997) Oxidative burst: an early plant response to pathogen infection. Biochem J $322: 681-692$.

57. Gozzo F (2004) Systemic acquired resistance in crop protection. Outlooks on Pest Manag. pp 20-23.

58. Ahmed SM (2010) Effects of salicylic acid, ascorbic acid and two fungicides in control of early blight disease and some physiological components of two varieties of potatoes. J Agric Res Kafer El-Shiekh Univ Egypt 36: 220-237.

59. Weir TL, Park SW, Vivanco JM (2004) Biochemical and physiological mechanisms mediated by allelochemicals. Curr Opin Plant Biol 7: 472-479.

60. Mayer AM, Harel E (1979) Polyphenoloxidases in plants. Phytochem. 18: 193215.
61. Melo GA Shimizu MM, Mazzafera P (2006) Polyphenoloxidase activity in coffee leaves and its role in resistance against the coffee leaf miner and coffee leaf rust. Phytochemistry 67: 277-285.

62. Lamb C, Dixon RA (1997) THE OXIDATIVE BURST IN PLANT DISEASE RESISTANCE. Annu Rev Plant Physiol Plant Mol Biol 48: 251-275.

63. Singh DP, Moore CA, Gilliland A, Carr JP (2004) Activation of multiple antiviral defence mechanisms by salicylic acid. Mol Plant Pathol 5: 57-63.

64. Aldesuquy HS, Makarios AT, Awad HA (1998) Effect of two antitranspirants on growth and productivity of salt treated wheat plants. Egypt J Sci Physio 22: 189-211.

65. Ali MB, Hahn EJ, Paek KY (2007) Methyl jasmonate and salicylic acid induced oxidative stress and accumulation of phenolics in Panax ginseng bioreactor root suspension cultures. Molecules 12: 607-621.

66. Mandal S, Mitra A (2007) Reinforcement of cell wall in roots of Lycopersicon esculentum through induction of phenolic compounds and lignin by elicitors. Physiol Mol Plant Pathol 71: 201-209.

67. El-Khallal SM (2007) Induction and modulation of resistance in tomato plants against Fusarium wilt disease by bioagent fungi (Arbuscular Mycorrhiza) and/o hormonal elicitors (jasmonic Acid \& salicylic Acid): 2- changes in the antioxidant enzymes, phenolic compounds and Pathogen Related- proteins. Aust J Basic Appl Sci 1: 717-732.

68. Beckman $\mathrm{CH}$, Mueller VC, Mace ME (1974) The stabilization of artificial and natural cell wall membranes by phenolic infusion and its relation to wilt disease resistance. Phytopathol 64: 1214-1220.

69. Kruger WM, Carver TW, Zeyen RJ (2002) Phenolic inhibition of penetration resistance to Blumeria graminis $\mathrm{f}$. $\mathrm{sp}$. hordei in barley near isogenic lines containing seven independent resistance genes or alleles. Physiol Mol Plant Pathol 61: 41-51

70. Carrasco AE, Serrano ML, Zapata JM, Sabater B, Martín M (2001) Oxidation of phenolic compounds from Aloe barbadensis by peroxidase activity: Possible involvement in defence reactions. Plant Physiol Biochem 39: 521-527.

71. Hahlborck K, Sheel D (1989) Physiology and molecular biology of phenylpropanoid metabolism. Plant Mol Biol 40: 347-369.

72. Hagerman AE, Robbins CT (1987) Implications of soluble tannin-protein complexes for tannin analysis and plant defense mechanisms. J Chem Ecol 13: $1243-1259$.

73. Sarma BK, Singh UP (2003) Ferulic acid may prevent infection of Cicer arietinum by Sclerotium rolfsii. World J Microbiol Biotechnol 19: 123-127.

74. Petkovsek MM, Stampar F, Veberic R (2009) Accumulation of phenolic compounds in apple in response to infection by the scab pathogen, Venturia inaequalis. Physiol Mol Plant Pathol 74: 60-67.

75. Mandal S, Mallick N, Mitra A (2009) Salicylic acid-induced resistance to Fusarium oxysporum f. sp. Iycopersici in tomato. Plant Physiol Biochem 47 642-649.

76. Panina YS, Gerasimova NG, Chalenko GI, Vasyukova NI, Ozeretskovskaya OL (2005) Salicylic acid and phenylalanine ammonia-lyase in potato plants infected with the causal agent of late blight. Russ J Plant Physiol 52: 511-515.

77. Chen JY, Wen PF, Kong WF, Pan QH, Zhan JC (2006) Effect of salicylic acid on phenylpropanoids and phenylalanine ammonialyase in harvested grape berries. Posthar Biol Tech 40: 64-72.

78. Dong J, Wan G, Liang Z (2010) Accumulation of salicylic acid-induced phenolic compounds and raised activities of secondary metabolic and antioxidative enzymes in Salvia miltiorrhiza cell culture. J Biotechnol 148: 99-104. 